\title{
Molecular mimicry by Mycoplasma pneumoniae to evade the induction of adherence inhibiting antibodies
}

\author{
E. JACOBS, A. BARTL, K. OBERLE and E. SCHILTZ* \\ Institute for Medical Microbiology and Hygiene and * Institute for Organic and Biochemistry, University of Freiburg, \\ D-79008 Freiburg, Germany
}

\begin{abstract}
Summary. Specific regions of adherence binding sites and epitopes of the P1 adhesin of Mycoplasma pneumoniae were synthesised as octapeptides and used as targets in a modified enzyme-linked immunosorbent assay. Acute phase and convalescent sera from 10 patients with $M$. pneumoniae infection were tested for antibody reactivity to these octapeptides. In convalescent sera, antibody activities were directed against octapeptides of the epitope regions, whereas no antibody activity was found in acute or convalescent sera to octapeptides of adherence-mediating binding sites. The non-responsiveness to adherence-mediating binding sites could be explained partially from the results of cross-reactivity experiments with adherence-inhibiting anti-P1 adhesin monoclonal antibodies (MAbs). Two of these MAbs showed cross-reactions with intracellular antigens of eukaryotic cell lines in immunofluorescence microscopy experiments. The cross-reacting antigens were isolated and characterised as glyceraldehyde-3-phosphate dehydrogenase and 2-phospho-D-glycerate hydrolyase. Antigenic mimicry of eukaryotic structures by functional sites of the P1 adhesin of $M$. pneumoniae may influence the pathogenesis of $M$. pneumoniae infection.
\end{abstract}

\section{Introduction}

Mycoplasma pneumoniae is a common cause of community-acquired respiratory tract infection and $c$. 5-10\% of $M$. pneumoniae-infected patients suffer from interstitial pneumonia. ${ }^{1}$ Adherence of $M$. pneumoniae to respiratory epithelial cells of the bronchial tract is a prerequisite for colonisation and propagation of the pathogen. The major P1 adhesin of $M$. pneumoniae, which is concentrated in a tip structure of mycoplasmal cells, mediates contact to epithelial cells. ${ }^{2}$ Establishment of anti-P1 protein monoclonal antibodies (MAbs) with adherence-inhibiting activity allowed the amino-acid sequences of the MAb binding sites to be characterised. $^{3}$ At least three domains of the P1 protein - the N-terminal region and the D1- and D2regions - are necessary to build up a tertiary adherence complex. However, on mapping the P1 primary amino-acid sequence for epitopes with patients' sera, several immunogenic regions were detected, none of which was identical to the binding sites of adherenceinhibiting MAbs. ${ }^{4-6}$

This serological study was designed to clarify whether adherence-mediating sites are of low or no

Received 17 Feb. 1995; accepted 11 May 1995. immunogenic capacity under natural conditions of human respiratory infection due to $M$. pneumoniae. Paired sera were collected from patients with respiratory symptoms who also had chest radiographs indicating an interstitial pneumonia and a positive culture of $M$. pneumoniae from nasopharyngeal aspirates. Acute phase and convalescent sera were tested for binding activities to oligopeptides which were synthesised according to known amino-acid sequences of epitopes or adherence-mediating binding sites of the P1 adhesin. Anti-P1 protein MAbs were also used to investigate possible cross-reactions between host antigens and $M$. pneumoniae.

\section{Materials and methods}

\section{Clinical samples}

$M$. pneumoniae was cultured from nasopharyngeal aspirates ${ }^{7}$ of patients with clinical signs of pneumonia and chest radiographs indicating an interstitial lung infiltration. The acute phase serum, together with the nasopharyngeal aspirate, was obtained from each patient on the day of admission to hospital and a second serum (convalescent sample) was collected 7-11 days later. 
Table. Octapeptide sequences and corresponding control sera used in the Pepscan ELISA

\begin{tabular}{|c|c|c|c|}
\hline Octapeptide & Sequence & $\begin{array}{c}\text { P1 } \\
\text { protein } \\
\text { position* }\end{array}$ & $\begin{array}{l}\text { Anti- } \\
\text { octapeptide } \\
\text { antibodies }\end{array}$ \\
\hline Al & $\mathrm{NH}_{2}-(231)-\mathrm{E}-\mathrm{V}-\mathrm{K}-\mathrm{K}-\mathrm{K}-\mathrm{S}-\mathrm{D}-\mathrm{S}$ & N-region & MAb P1.62 \\
\hline $\mathrm{A} 2$ & $\mathrm{NH}_{2}^{2}-(851)-\mathrm{E}-\mathrm{N}-\mathrm{H}-\mathrm{T}-\mathrm{K}-\mathrm{F}-\mathrm{T}-\mathrm{S}$ & D1-region & MAb P1.62 \\
\hline A3 & $\mathrm{NH}_{2}-(921)-\mathrm{N}-\mathrm{A}-\mathrm{L}-\mathrm{S}-\mathrm{F}-\mathrm{T}-\mathrm{N}-\mathrm{K}$ & D1-region & MAb P1.26 \\
\hline A4 & $\mathrm{NH}_{2}-(1303)-\mathrm{D}-\mathrm{V}-\mathrm{V}-\mathrm{G}-\mathrm{V}-\mathrm{G}-\mathrm{R}-\mathrm{L}$ & D2-region & MAb P1.26 \\
\hline A5 & $\mathrm{NH}_{2}-(1391)-\mathrm{S}-\mathrm{V}-\mathrm{N}-\mathrm{P}-\mathrm{K}-\mathrm{M}-\mathrm{V}-\mathrm{R}$ & D2-region & MAb 58 \\
\hline A6 & $\mathrm{NH}_{2}-(1407)-\mathrm{N}-\mathrm{E}-\mathrm{Q}-\mathrm{S}-\mathrm{L}-\mathrm{G}-\mathrm{L}-\mathrm{R}$ & D2-region & MAb 51 \\
\hline $\mathrm{N}$ & $\mathrm{NH}_{2}-(1)-\mathrm{N}-\mathrm{A}-\mathrm{I}-\mathrm{N}-\mathrm{P}-\mathrm{R}-\mathrm{L}-\mathrm{T}$ & $\mathrm{N}$-region & PS \\
\hline B1 & $\mathrm{NH}_{2}-(542)-\mathrm{P}-\mathrm{R}-\mathrm{L}-\mathrm{L}-\mathrm{Y}-\mathrm{D}-\mathrm{E}-\mathrm{L}$ & Dl-region & PS \\
\hline B2 & $\mathrm{NH}_{2}-(633)-\mathrm{Y}-\mathrm{I}-\mathrm{Y}-\mathrm{P}-\mathrm{Y}-\mathrm{R}-\mathrm{Y}-\mathrm{S}$ & D1-region & PS \\
\hline B3 & $\mathrm{NH}_{2}-(751)-\mathrm{W}-\mathrm{I}-\mathrm{G}-\mathrm{N}-\mathrm{G}-\mathrm{Y}-\mathrm{R}-\mathrm{Y}$ & D1-region & PS \\
\hline B4 & $\mathrm{NH}_{2}-(1456)-\mathrm{P}-\mathrm{F}-\mathrm{N}-\mathrm{Q}-\mathrm{W}-\mathrm{P}-\mathrm{D}-\mathrm{Y}$ & D2-region & PS \\
\hline K1 & $\mathrm{NH}_{2}-\mathrm{P}-\mathrm{L}-\mathrm{A}-\mathrm{G}-\mathrm{G}-\mathrm{G}-\mathrm{G}-\mathrm{G}$ & NS & MAb K1 \\
\hline $\mathrm{K} 2$ & $\mathrm{NH}_{2}-\mathrm{G}-\mathrm{L}-\mathrm{A}-\mathrm{G}-\mathrm{G}-\mathrm{G}-\mathrm{G}-\mathrm{G}$ & NS & MAb K2 \\
\hline
\end{tabular}

PS, patient sera with anti-octapeptide antibody activity. ${ }^{4}$

NS, octapeptide with no similarities to amino-acid sequences of the P1 protein.

* Position of the octapeptides within the P1 protein sequence (see fig. 1).

\section{Serological tests}

Paired sera were tested for anti- $M$. pneumoniae antibodies in two different enzyme-linked immunoassays (ELISA), based on sonicated $M$. pneumoniae whole cell antigen preparations or on the isolated P1 protein as antigen. ${ }^{8}$ Antibodies to defined octapeptides were also measured in these sera by the Pepscan ELISA (CRB, Cambridge, England). Octapeptides were synthesised on to polyethylene rods in duplicate according to amino-acid sequences of parts of the P1 protein which have been shown previously either to be involved in adherence (A1-A6) or to be epitopes (Nand B1-B4) (table). ${ }^{3-5}$

Patients' sera or control sera (table) were pre-diluted 1 in 400 in blocking buffer-bovine serum albumin $1 \% \mathrm{w} / \mathrm{v}$, ovalbumin $1 \% \mathrm{w} / \mathrm{v}$ and Tween $201 \% \mathrm{v} / \mathrm{v}$ in PBS (0.14 M NaCl, 0.01 M sodium phosphate, $\mathrm{pH} 7 \cdot 2)$. Pre-diluted serum $(100 \mu \mathrm{l})$ was incubated with each of the octapeptides for $1 \mathrm{~h}$ at $37^{\circ} \mathrm{C}$. After incubation, the peptide trays were washed three times in Tween 20 $0.05 \%$ in PBS and $150 \mu$ of alkaline phosphataseconjugated rabbit anti-human IgG (patients' sera) or goat anti-mouse IgG (control MAbs), which had been diluted according to the manufacturers' instructions (Dianova, Hamburg, Germany) were added. The trays were incubated for $1 \mathrm{~h}$ at $37^{\circ} \mathrm{C}$ and washed four times, before $150 \mu \mathrm{l}$ of substrate solution (p-nitrophenyl phosphate $1 \mathrm{mg} / \mathrm{ml}$ in diethanolamine buffer, $\mathrm{pH} 9 \cdot 6$ ) were added, and the trays were incubated again for $1 \mathrm{~h}$ at $37^{\circ} \mathrm{C}$. The absorbance of the coloured product was measured at $405 \mathrm{~nm}$ with an ELISA multiscan photometer (Titertek Multiscan MCC). ${ }^{4}$

\section{Cell lines and immunofluorescence microscopy}

M. pneumoniae strain $\mathrm{FH}$ was grown at $37^{\circ} \mathrm{C}$ in Roux bottles in $50 \mathrm{ml}$ of Hayflick's modification of Edward's medium. ${ }^{9}$ Glass-adherent mycoplasmas were harvested after $48 \mathrm{~h}$ by centrifugation, washed twice with PBS and stored at $-20^{\circ} \mathrm{C}$.

Hybridoma cell lines (MAbs P1.26, P1.62, M51 and $\mathrm{M} 58^{3}$ ) were cultured in serum-free RPMI medium (RPMI-1640 containing $1 \mathrm{~mm}$ sodium pyruvate, penicillin $50 \mathrm{U} / \mathrm{ml}$, streptomycin $50 \mu \mathrm{g} / \mathrm{ml}$, $2 \mathrm{mM}$ L-glutamine (Sigma) and BM-Condimed Hl, Boehringer, $5 \%$ ). The supernates were used without further concentration of MAb in immunofluorescence tests and immunoblots.

The following immortalised cell lines were used: HeLa (human cervical carcinoma cell line, ATCC CCL 2); HEp-2 (epidermoid carcinoma, larynx, human cell line, ATCC CCL 23); HL-60 (promyelotic human leukemia cell line, ATCC CCL 240); MRC-5 (lung, diploid, human cell line, ATCC CCL 171); ACHN (renal adenocarcinoma, human cell line, ATCC CRL 1611); WiDr (colon, adenocarcinoma, human cell line, ATCC CCL218); and Vero (kidney, African green monkey cell line, ATCC CCL 81).

Cell lines were grown at $37^{\circ} \mathrm{C}$ in $\mathrm{CO}_{2} 5 \%$ in air in Dulbecco's modified Eagle's minimal essential medium, supplemented with fetal calf serum $5 \%$, gentamicin $50 \mu \mathrm{g} / \mathrm{ml}$ and glutamine $0.3 \mathrm{mg} / \mathrm{ml}$. All eukaryotic cell lines were tested for mycoplasmal contamination by culture and the polymerase chain reaction (PCR) based on a common primer set which detects mycoplasmas in cultures. ${ }^{10}$ Contaminated cultures were cured by incubation with ciprofloxacin $50 \mu \mathrm{g} / \mathrm{ml}$ for three cell cycles. Cured cultures were retested for mycoplasmas by culture and PCR.

Mycoplasma-free cells were plated on glass cover slides, fixed for $10 \mathrm{~min}$ in acetone:ethanol $(1: 1)$ at $-20^{\circ} \mathrm{C}$ and air dried. For indirect immunofluorescence staining, cells were first incubated with the different hybridoma supernates (MAbs P1.26, $\mathrm{P} 1.62, \mathrm{M} 51$ and M58) for $45 \mathrm{~min}$ at $37^{\circ} \mathrm{C}$, washed with PBS and incubated for $30 \mathrm{~min}$ at $37^{\circ} \mathrm{C}$ with biotinylated goat anti-mouse antibody (Dianova, 
Hamburg, Germany) diluted 1 in 100 in Tween 20 $0.05 \%$ in PBS. The cells were washed, incubated with fluorescein isothiocyanate (FITC)-conjugated streptavidin, washed again and then evaluated with a Zeiss Axiophot microscope according to Fritsche et al. ${ }^{11}$ Control cells were incubated with RPMI medium alone in the first step.

\section{Detection and characterisation of cross-reacting} proteins

M. pneumoniae or eukaryotic cells were solubilised in electrophoresis sample buffer. One-dimensional analytical SDS-PAGE and immunoblotting of electrophoretically separated protein patterns were performed as described previously. ${ }^{12}$

The supernate of sonicated and centrifuged $(27000 \mathrm{~g}$ for $1 \mathrm{~h}$ ) eukaryotic HL-60 cells was used as a crude cytosolic protein fraction. For further characterisation of eukaryotic cell proteins, the cytosolic fraction was separated by SDS-PAGE, transferred from the gel to a PVDF (polyvinylidenedifluoride) membrane (Immobilon-P; Millipore), followed by immuno-staining with $\mathrm{MAb}$ supernates. Gas-phase sequencing of immobilised peptides was performed on Coomassiestained bands which were cut out of transfer membranes. ${ }^{13}$ An N-terminal blocked protein was electroeluted out of SDS-PAGE gels, ${ }^{14}$ cleaved chemically with cyanogen bromide, and the resulting protein fragments were separated electrophoretically and transferred to a PVDF membrane for sequencing of the $N$-termini of internal fragments. ${ }^{13}$

Glyceraldehyde-3-phosphate dehydrogenase (GADH from rabbit muscle; EC 1.2.1.12) and 2-phosphoD-glycerate hydrolyase (enolase from rabbit muscle; EC 4.2.1.11) were purchased as reference proteins (Sigma).

Amino-acid sequences of the $\mathrm{N}$-termini of the sequenced eukaryotic proteins were compared by means of the SwissProt protein sequence data library (DKFZ, Heidelberg).

\section{Results}

Antibody responses against epitopes and adherencemediating sites of the $P 1$ protein

Ten patients with a positive culture of $M$. pneumoniae and clinical and radiological signs of pneumonia were enrolled in the study. In acute phase sera, no or only low antibody activities were found in the $\mathrm{Pl}$ protein ELISA and in the $M$. pneumoniae whole-cell antigen ELISA, whereas all 10 convalescent sera showed high antibody responses in the P1 ELISA $\left(\mathrm{OD}_{405} \geqslant 1 \cdot 4\right)$ and $M$. pneumoniae-ELISA $\left(\mathrm{OD}_{405} \geqslant 1 \cdot 6\right)$. These paired sera were tested for antibody activity against amino-acid sequences that have been characterised as epitopes of the P1 protein (N and B1-4) or as adherence-mediating sites (A1-6). Acute phase sera showed no or only weak binding to the epitopes and no activity against the adherence-mediating epitopes. Compared to results with the control synthetic peptides $\mathrm{K} 1$ and $\mathrm{K} 2$ and those obtained with the acute sera, the convalescent sera showed elevated antibody activities to synthetic peptides of the epitope group. In contrast, antibody activity directed to the adherencemediating group of synthetic peptides was not detectable in convalescent sera (fig. 1).

\section{Cross-reactivity}

The anti-P1 protein MAbs (P1.26, P1.62, M51 and M58) were tested for cross-reactions with different human tumour cell lines. MAbs P1.26 and P1.62 showed cross-reactions with all eukaryotic cell lines tested in immunofluorescence microscopy. Both MAbs showed homogeneous labelling of the cytoplasm excluding the nucleus area, as shown for MAb P1.62 with HeLa cells (fig. 2). In immunoblots MAb P1.62 showed cross-reaction with a $53-\mathrm{kDa}$ protein and MAb P1.26 with a $36-\mathrm{kDa}$ protein. In contrast to HeLa, MRC-5, ACHN, WiDr and HL-60 cell lines, the cross-reacting protein binding MAb P1.26 in Vero cells was slightly different with a mol. wt of $c .38 \mathrm{kDa}$ (fig. 3). MAbs M51 and M58 showed no cross-reaction with eukaryotic cells in either immunofluorescence microscopy or immunoblots (results not shown).

\section{Characterisation of cross-reacting proteins}

The supernate of the crude cytoplasmic fraction of HL-60 cells was separated by SDS-PAGE and proteins were transferred to PVDF membranes (fig. 4). The 36- and 53-kDa proteins were cut out of the PVDF membrane for amino-acid gas-phase sequencing. The first $15 \mathrm{~N}$-terminal amino acids of the $36-\mathrm{kDa}$ protein were $\mathrm{NH}_{2}-(1)-\mathrm{G}-\mathrm{K}-\mathrm{V}-\mathrm{K}-\mathrm{V}-\mathrm{G}-\mathrm{V}-\mathrm{N}-\mathrm{G}-\mathrm{F}-\mathrm{G}-\mathrm{R}-\mathrm{I}-\mathrm{G}-\mathrm{R}$ whereas the N-terminus of the $53-\mathrm{kDa}$ protein seemed to be blocked. Therefore, the 53-kDa protein was cut out of 10 SDS-PAGE gels and electro-eluted out of the gel matrix. Cyanogen bromide-cleaved fragments were separated and transferred to PVDF membranes to sequence the $\mathrm{N}$-termini of the various $53-\mathrm{kDa}$ fragments (fig. 5). The $\mathrm{N}$-terminus of the $28-\mathrm{kDa}$ fragment was not sequenceable. The $22-\mathrm{kDa}$ fragment revealed the sequence $\mathrm{NH}_{2}-\mathrm{R}-\mathrm{I}-\mathrm{G}-\mathrm{A}-\mathrm{E}-\mathrm{V}-\mathrm{Y}-\mathrm{H}-\mathrm{N}-\mathrm{L}-\mathrm{K}-\mathrm{N}-\mathrm{V}-\mathrm{I}-\mathrm{K}$.

\section{Prediction and confirmation}

The amino-acid sequences of the $\mathrm{N}$-terminus of the $36-\mathrm{kDa}$ protein and of the internal fragment of the 53kDA protein were compared with known protein sequences in a protein sequence data library. The sequence of the $36-\mathrm{kDa}$ protein revealed complete identity with glyceraldehyde-3-phosphate dehydrogenase (GAPDH; EC 1.2.1.12) and the internal sequence (N-terminal position 182) of the $53-\mathrm{kDa}$ protein with 2-phospho-D-glycerate hydrolyase (enolase; EC 4.2.1.11). To confirm the sequence homologies between the GAPDH and enolase with the 


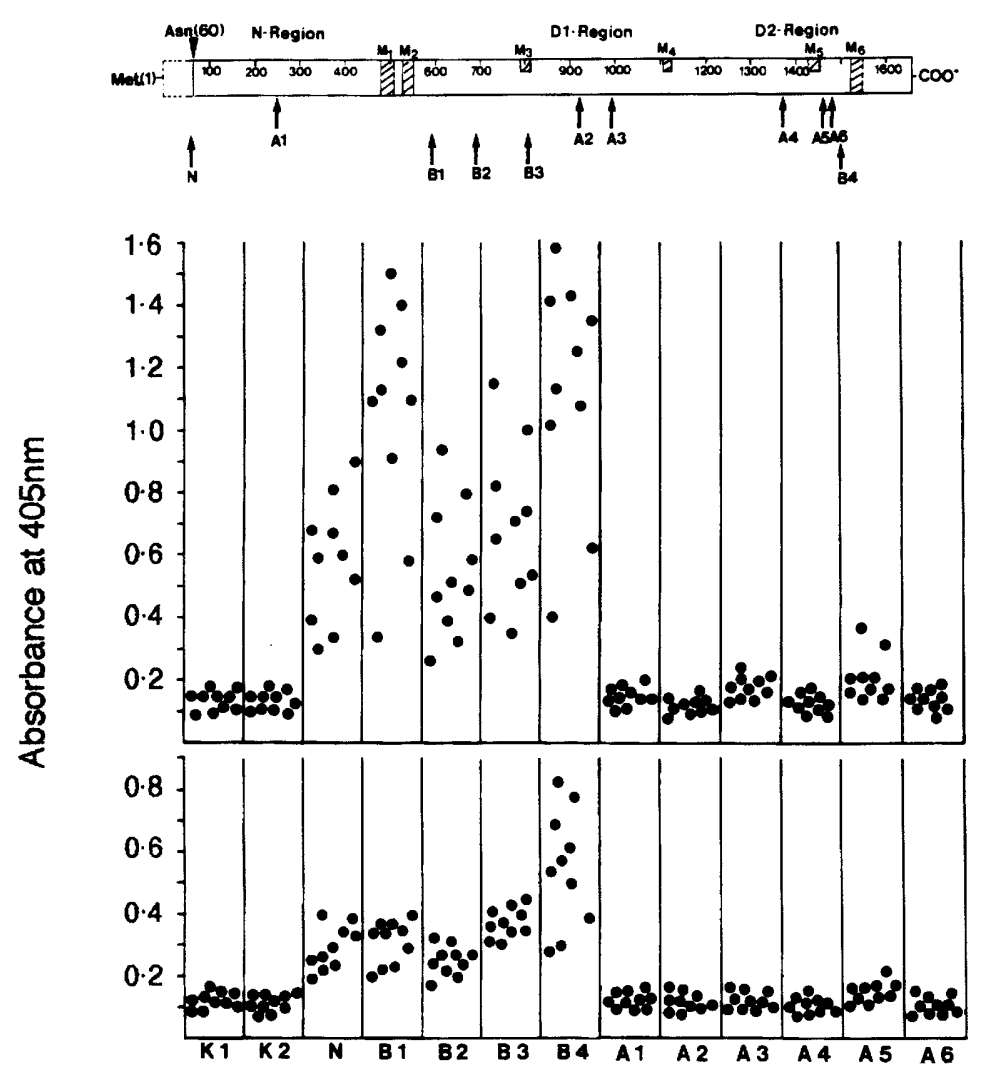

Fig. 1. Acute (lower insert) and convalescent (upper insert) sera of patients with $M$. pneumoniae pneumonia, tested for antibody (absorbance at $405 \mathrm{~nm}$ ) to octapeptides of amino-acid sequences characterised as epitopes (N and B1-4) or as adherence-mediating sites (A1-6) of the P1 protein. The P1 protein diagram (uppermost) shows N-, A- and B-positions and membrane-associated helices M1-6. ${ }^{3}$ Octapeptides K1 and $\mathrm{K} 2$ were controls.

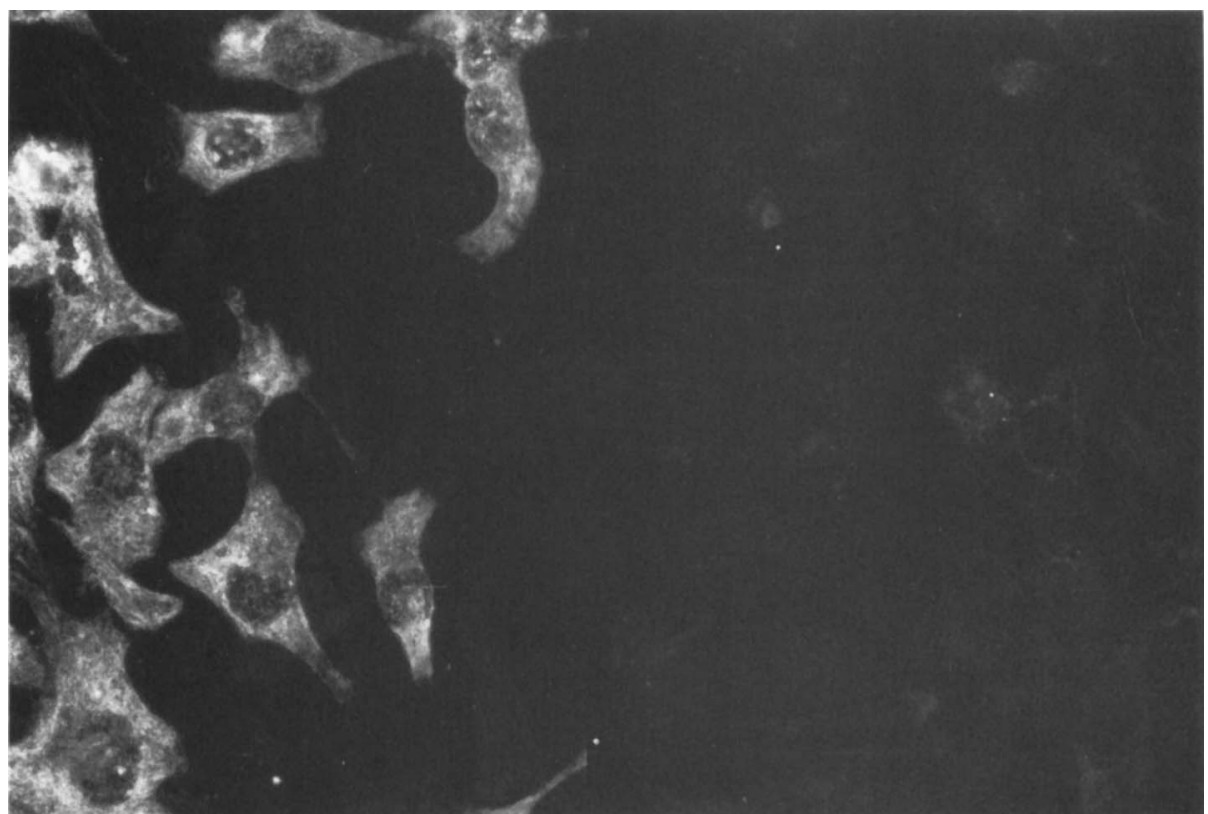

Fig. 2. Cross-reaction of the anti-P1 protein MAb P1.62 with HeLa cells in indirect immunofluorescence microscopy (left). As a control, HeLa cells were incubated without MAb suspension but with the indicator complex (right).

amino-acid sequences of the 36- and 53-kDa proteins, respectively, defined enzymes were tested in immunoblots in parallel to human cell lines. The immunoblot in fig. 6 was developed with MAb P1.26. The MAb showed cross-reaction with GAPDH from rabbit muscles which was of the same mol. wt as the crossreacting protein in HEp-2 cells. A slight difference in mol. wt was found on comparing the MAb P1.62 cross-reacting band of the human HEp-2 cell with the enolase isolated from rabbit muscle (fig. 7).

\section{Discussion}

The "gold standard" in the diagnosis of $M$. pneumoniae infection is still culture, ${ }^{7}$ although modern 


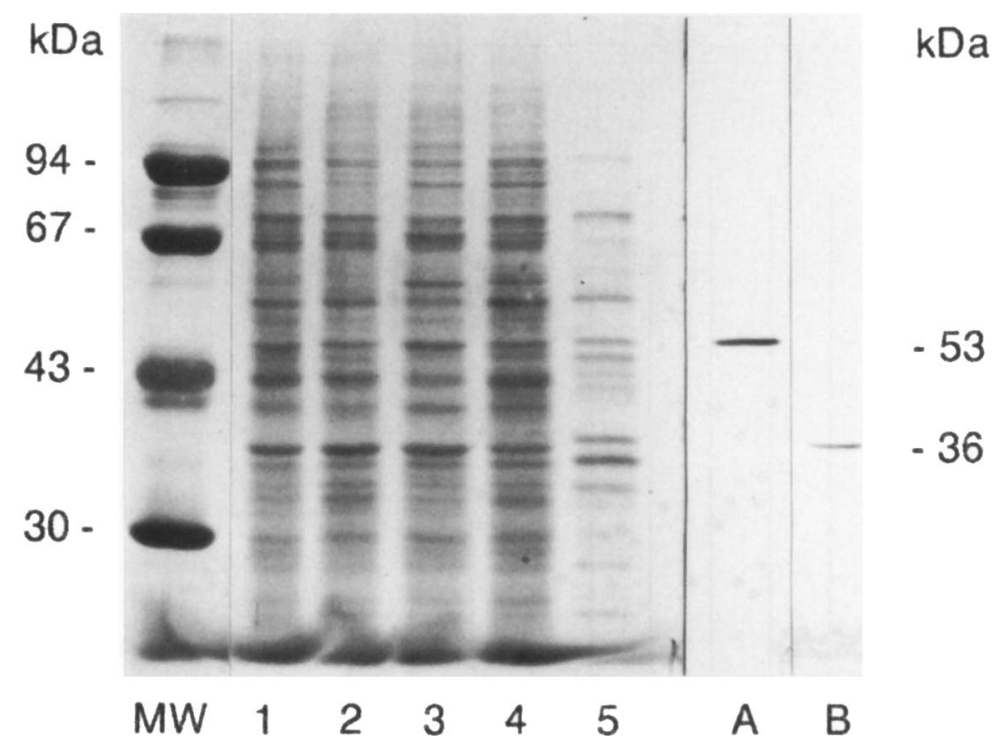

Fig. 3. Cross-reactions in immunoblots of (A) MAb P1.62 and (B) MAb P1.26 with 53- and 36-kDa proteins of HL-60 cells, respectively. Amidoblack-stained protein patterns of 1 , HeLa; $2, \mathrm{MRC}-5 ; 3, \mathrm{ACHN} ; \mathbf{4}, \mathrm{WiDr} ; \mathbf{5}$, Vero cell lines showed common protein bands within the 53- and $36-\mathrm{kDa}$ mol. wt ranges.

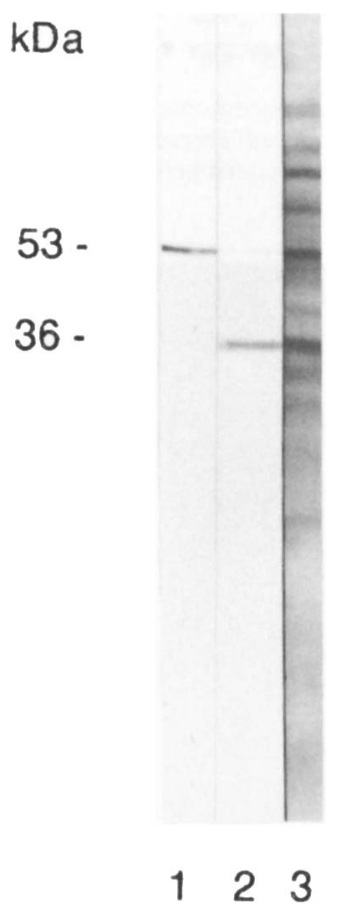

Fig. 4. The positions of $1,53-\mathrm{kDa} ; 2,36-\mathrm{kDa}$ proteins, were identified in immunoblots. The bands were cut out of a Coomassie blue-stained crude cytosol protein fraction of HL-60 cells (3) for Nterminal sequencing

diagnostic techniques such as direct antigen tests ${ }^{15}$ and $\mathrm{PCR}^{16}$ allow more rapid diagnosis. To find out whether adherence epitopes are antigenic during the natural course of infection, patients with $M$. pneumoniae-positive nasopharyngeal aspirates were enrolled in this study. Mainly due to the problems encountered in cultivating the fastidious $M$. pneumoniae, only 10 cases could be enrolled in a 4-year study period. $M$. pneumoniae-positive patients showed increasing antibody activities in convalescent sera, compared to the acute sera, in ELISA tests with $M$. pneumoniae whole-cell antigen preparations or the isolated $\mathbf{P} 1$ protein as antigen. The delayed response demonstrated by elevated antibody activity in most convalescent sera but not in acute sera is in agreement with results from studies using the complement fixation test in $M$. pneumoniae serology. ${ }^{17}$ In parallel with the elevated antibody activity to whole antigens found in convalescent sera, elevated antibody responses to octapeptides of the P1 protein epitope group were also detected in the Pepscan ELISA. In contrast, no antibodies were detected against adherence-mediating sites of the $\mathrm{P} 1$ adhesin in either acute or convalescent sera.

To find out whether the adherence-mediating regions might share antigenic determinants with host cells, different eukaryotic cell lines were tested for cross-reaction with four MAbs recognising different adherence-mediating binding sites. Two of the four MAbs showed distinct cross-reactions with the cytoplasmic enzymes GAPDH and enolase, which are both enzymes of the glycolytic pathway. Recently, it was shown that GAPDH is distributed homogeneously throughout the cytoplasm, excluding the nucleus and vesicles, and is associated with the actin cytoskeleton. ${ }^{18}$ This intracellular distribution is in accordance with the results of immunofluorescence studies with $\mathrm{MAb}$ P1.26.

Antigenic similarities between $M$. pneumoniae molecules and human GAPDH and enolase might be responsible for non-responsiveness or for a selflimitation of the immune response during natural infection with $M$. pneumoniae. In the pathogenesis of $M$. pneumoniae infection, the failure of induction of adherence-inhibiting antibodies might explain the prolonged isolation of $M$. pneumoniae from the res- 


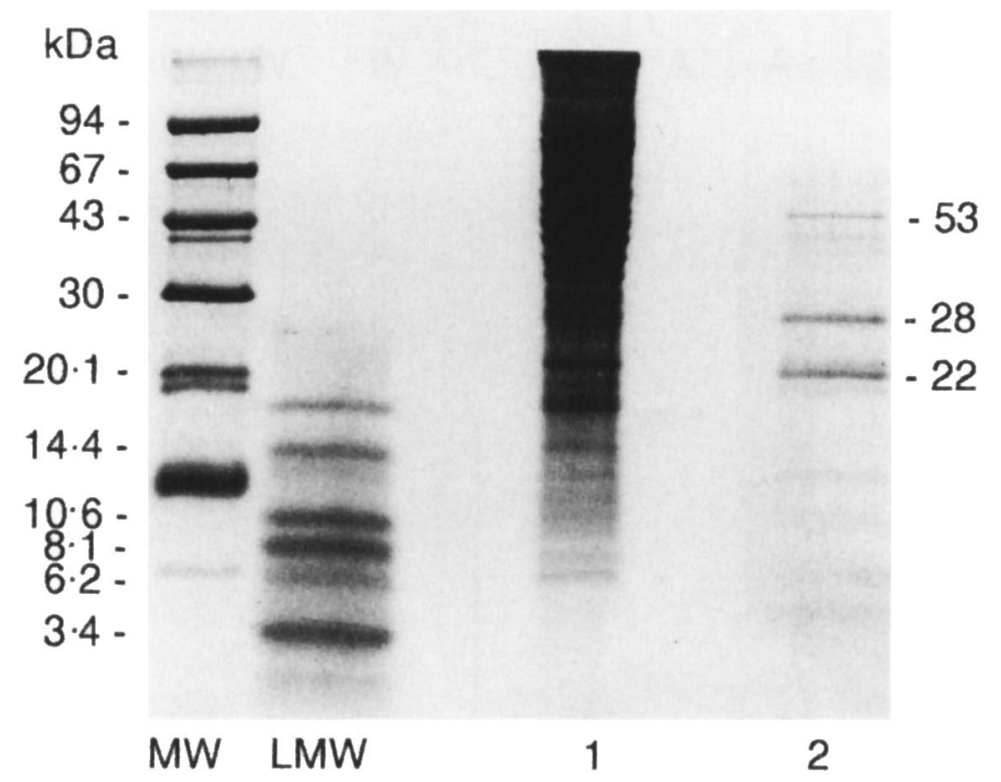

Fig. 5. SDS-PAGE patterns of HL-60 cell proteins (1), the cyanogen bromide-cleaved 53-kDa protein (2), and high-mol. wt (MW) and lowmol. wt (LMW) markers in a $10 \%$ gel.

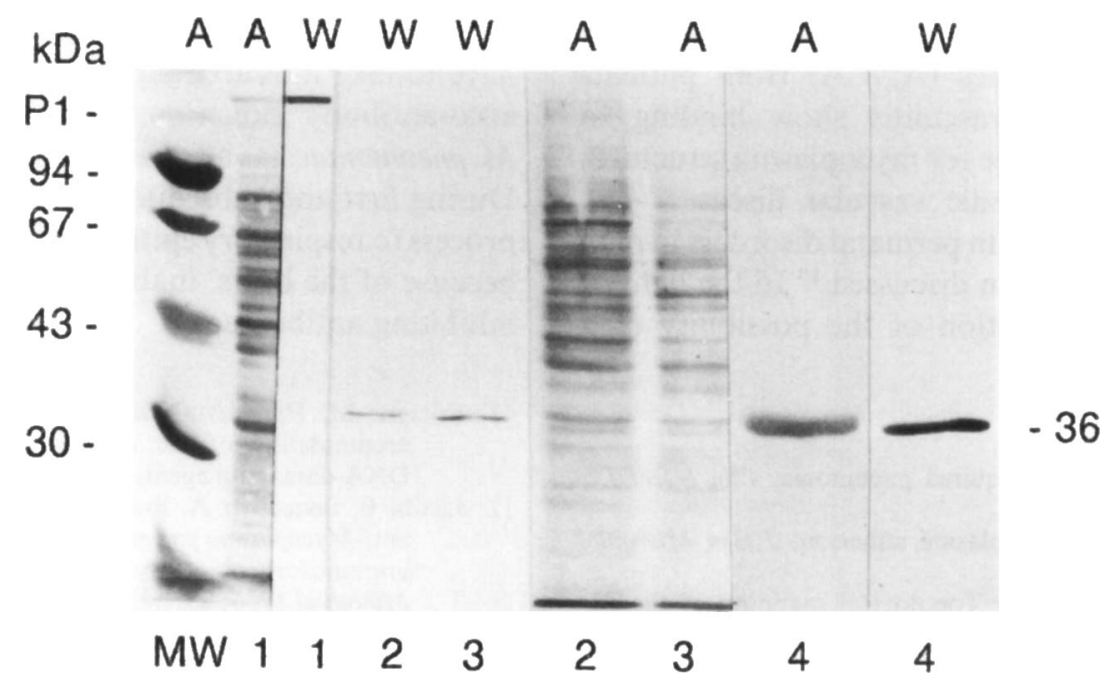

Fig. 6. Binding of MAb P1.26 to the P1 protein of M. pneumoniae (1) and cross-reactions with the 36-kDa protein of HeLa (2) and HL-60 (3) cells and GAPDH isolated from rabbit muscle (4) in immunoblots (W). A: amidoblack-stained protein profiles.

piratory tract of infected patients and the lack of protective immunity to subsequent infection with this pathogen. This hypothesis is supported by experiments with guinea-pigs. Pre-stimulation of animals with the isolated $\mathrm{P} 1$ protein did not protect animals against an experimental infection with $M$. pneumoniae. In contrast, vaccinated and infected animals showed an increased release of inflammatory cytokines and lympho-histiocyte infiltrations of lung tissues. ${ }^{19,20}$

The emerging questions are: (i) is it possible to break the non-responsiveness; (ii) would such adherence-inhibiting antibodies protect against subsequent infections; and (iii) what would be the sideeffects of these "auto-immune" antibodies? The de- velopment of auto-antibodies during $M$. pneumoniae infection is a well known phenomenon. Lind et al. ${ }^{21}$ have shown that more than half of patients suffering $M$. pneumoniae infection with positive complement fixation titres $(\geqslant 512)$ were also positive for autoantibodies to the mitotic spindle apparatus of eukaryotic cells and for cold agglutinin. In contrast to the recognised clinical association between cold agglutinin autoantibodies and intravascular haemolysis, ${ }^{17}$ anti-lymphocyte antibodies and antibodies to brain, lung, cardiolipin, smooth muscle and the mitotic spindle apparatus in patients with $M$. pneumoniae infections have not been shown to have an obvious role in pathogenicity. There may be a difference in 


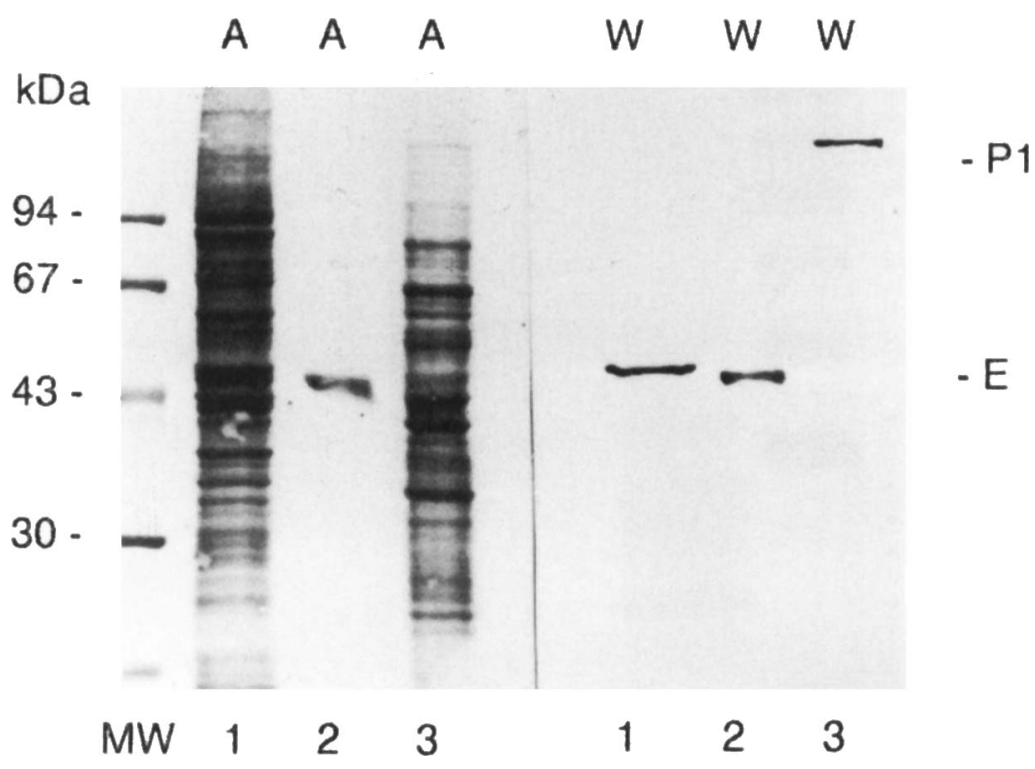

Fig. 7. Binding of the anti-P1 protein MAb P1.62 to HEp-2 cells (1), enolase isolated from rabbit muscle (2, E) and to the P1 protein (P1) of $M$. pneumoniae (3) in immunoblots (W). A : amidoblack-stained protein profiles

respect of autoantibody induction to $\alpha$-enolase. Approximately $40 \%$ of sera with anti-neutrophil cytoplasmic autoantibodies (ANCA) from patients with clinically proven vasculitis show binding to enolase. ${ }^{22}$ Moreover, a role for mycoplasma structures as auto-antigens in chronic vascular diseases, e.g., rheumatoid arthritis, and in perinatal disorders in man and in great apes has been discussed. ${ }^{23}$ In the light of these findings, consideration of the possibility of a

\section{References}

1. Marrie TJ. Community-acquired pneumonia. Clin Infect Dis $1994 ; 18: 501-515$.

2. Razin S, Jacobs E. Mycoplasma adhesion. J Gen Microbiol $1992 ; 138: 407-422$

3. Gerstenecker B, Jacobs E. Topological mapping of the P1adhesin of Mycoplasma pneumoniae with adherenceinhibiting monoclonal antibodies. J Gen Microbiol 1990 136: $471-476$

4. Jacobs E, Pilatschek A, Gerstenecker B, Oberle K, Bredt W Immunodominant epitopes of the adhesin of Mycoplasma pneumoniae. J Clin Microbiol 1990; 28: 1194-1197.

5. Jacobs E. Fuchte $\mathbf{K}$, Bredt W. Amino acid sequence and antigenicity of the amino-terminus of the $168 \mathrm{kDa}$ adherence protein of Mycoplasma pneumoniae. $J$ Gen Microbiol 1987; 133: 2233-2236.

6. Jacobs E. Mycoplasma pneumoniae virulence factors and the immune response. Rev Med Microbiol 1991; 2: 83-90.

7. Kenny GE, Kaiser GG, Cooney MK, Foy HM. Diagnosis of Mycoplasma pneumoniae pneumonia: sensitivities and specificities of serology with lipid antigen and isolation of the organism on soy peptone medium for identification of infections. J Clin Microbiol 1990; 28: 2087-2093.

8. Jacobs E, Buchholz A, Kleinmann B, Bredt W. Use of adherence protein of Mycoplasma pneumoniae as antigen for enzymelinked immunosorbent assay (ELISA). Isr J Med Sci 1987 ; 23: $709-712$

9. Hayflick L. Tissue cultures and mycoplasmas. Texas Reports on Biology and Medicine 1965; 23: 285-303

10. van Kuppeveld FJM, van der Logt JTM, Angulo AF et al. Genus- and species-specific identification of mycoplasmas by $16 \mathrm{~S}$ rRNA amplification. Appl Environ Microbiol 1992; 58: $2606-2615$ vaccine that could break non-responsiveness and protect the host from $M$. pneumoniae infection would have to take into account the potential side-effects of auto-antibody induction. Under natural conditions, $M$. pneumoniae has adapted to its host in a perfect way. During first and subsequent infections, the adherence process to respiratory epithelial cells cannot be blocked because of the hosts' inability to establish adherenceinhibiting antibodies.

11. Fritsche M, Haessler $C$, Brandner G. Induction of nuclear accumulation of the tumor-suppressor protein p53 by DNA-damaging agents. Oncogene 1993; 8: 307-318

12. Jacobs E, Bennewitz A, Bredt W. Reaction pattern of human anti-Mycoplasma pneumoniae antibodies in enzyme-linked immunosorbent assays and immunoblotting. $J$ Clin Microbiol 1986; 23 : 517--522.

13. Jacobs E, Gerstenecker B, Mader B. et al. Binding sites of attachment-inhibiting monoclonal antibodies and of patients on peptide fragments of the Mycoplasma pneumoniae adhesin. Infect Immun 1988; 57: 685-688.

14. Jacobs E, Clad A. Electroelution of fixed and stained membrane proteins from preparative sodium dodecyl sulfatepolyacrylamide gels into a membrane trap. Anal Biochem 1986; 154: 583-589.

15. Kleemola M, Räty R, Karjalainen J, Schuy W, Gerstenecker B, Jacobs E. Evaluation of an antigen-capture enzyme immunoassay for rapid diagnosis of Mycoplasma pneumoniae infection. Eur J Clin Microbiol Infect Dis 1993 12: 872-875.

16. Bernet C, Garret M, de Barbeyrac B, Bebear C, Bonnet J. Detection of Mycoplasma pneumoniae by using the polymerase chain reaction. J Clin Microbiol 1989; 27 2492-2496.

17. Jacobs E. Serological diagnosis of Mycoplasma pneumoniae infections: a critical review of current procedures. Clin Infect Dis 1993; 17 Suppl 1: S79-82.

18. Minaschek G, Groschel-Stewart U, Blum S, Bereiter-Hahn J. Microcompartmentation of glycolytic enzymes in cultured cells. Eur J Cell Biol 1992; 58: 418-428.

19. Pietsch K, Ehlers S, Jacobs E. Cytokine gene expression in the lungs of BALB/c mice during primary and secondary intranasal infections with Mycoplasma pneumoniae. Microbiology 1994; 140 : 2043-2048. 
20. Jacobs E, Stuhlert A, Drews M. et al. Host reactions to Mycoplasma pneumoniae infections in guinea-pigs preimmunized systematically with the adhesin of this pathogen. Microb Pathog 1988; 5: 259-265.

21. Lind K, Hoier-Madsen M, Wiik A, Clyde WA. Antibodies to the mitotic spindle apparatus in patients with Mycoplasma pneumoniae infection. Immunol Infect Dis 1992; 2: 249-255.
22. Moodie FD, Leaker B, Cambridge G, Totty NF, Segal AW. Alpha-enolase: a novel cytosolic autoantigen in ANCA positive vasculitis. Kidney Int 1993; 43: 675-681.

23. Clark HW. The potential role of mycoplasmas as autoantigens and immune complexes in chronic vascular pathogenesis. Am J Primatol 1991; 24: 235-243. 